\title{
Degradation of Methylene Blue Using Cadmium Sulfide Photoanode in Photofuel Cell System with Variation of Electrolytes
}

\author{
Gunawan $^{1, *}$, Abdul Haris ${ }^{1}$, Didik Setiyo Widodo ${ }^{1}$, Linda Suyati ${ }^{1}$, and Wilman Septina ${ }^{2}$ \\ ${ }^{1}$ Department of Chemistry, Faculty of Science and Mathematics, Diponegoro University, \\ Jl. Prof. H. Soedarto, S.H., Tembalang Semarang 50275, Indonesia \\ ${ }^{2}$ Hawaii Natural Energy Institute, University of Hawai'i at Mānoa (UHM), 1680 East West Road, POST 109 Honolulu, HI 96822, \\ United States
}

*Corresponding author:

tel: $+62-24-7474754$

email: gunawan@live.undip.ac.id

Received: January 4, 2020

Accepted: February 19, 2020

DOI: $10.22146 / \mathrm{ijc} .53131$

\begin{abstract}
Methylene blue degradation carried out using cadmium sulfide (CdS) photoanode in photofuel cell (PFC) had been done. CdS synthesized by chemical bath deposition (CBD) on the FTO substrate was used as anode and platinum as a cathode in photoelectrochemical studies. Characterization of CdS thin film was done using EDX, XRD, SEM, Raman, UV-Vis absorption spectrophotometer as well as photocurrent test of the CdS thin film under illumination using potentiostat with the three-electrode system. The EDX result indicated the presence of CdS with an elemental composition of Cd rich. $X R D$ showed the appearance of CdS crystals in cubic and hexagonal formations. SEM image of CdS gave results in the form of crystals of less than 1 rm. Raman spectrum showed the appearance of CdS peaks. The bandgap of CdS was estimated to be $2.38 \mathrm{eV}$, and the photocurrent test confirmed that the film had a property of n-type semiconductor. Application of CdS thin film as a photoanode in the PFC system using $100 \mathrm{mg} / \mathrm{L}$ methylene blue solution showed degradation up to $48 \%$ for $2.5 \mathrm{~h}$ using a $4 \mathrm{~cm}^{2}$ photoanode, and the maximum potential of $0.8 \mathrm{~V}$ was obtained with a photoanode area of $1 \mathrm{~cm}^{2}$.
\end{abstract}

Keywords: cadmium sulphide; photoanode; photofuel cell; methylene blue

\section{- INTRODUCTION}

Recently, a photofuel cell (PFC) has attracted the attention of the scientific community as a potential wastewater treatment technology that can generate electricity from chemical energy conversion from organic pollutants [1-9]. Generally, PFC consists of a photoanode in the form of a semiconductor photocatalyst and a cathode, usually of platinum (Fig. 1). The photocatalyst undergoes photoexcitation upon light illumination and generates electron-hole pairs. The electrons will be excited from the valence band (VB) to the conduction band $(\mathrm{CB})$ of the photoanode and flow to the cathode through the outer circuit to produce electricity. Meanwhile, the holes will oxidize and destroy organic pollutants, or react with $\mathrm{OH}^{-}$or $\mathrm{H}_{2} \mathrm{O}$ to form hydroxyl radical $\left(\mathrm{OH}^{*}\right)$ through $\mathrm{H}_{2} \mathrm{O}$ oxidation. The resulting $\mathrm{OH}^{*}$ has a very strong oxidation potential $(2.80 \mathrm{~V})$, which is capable of oxidizing organic pollutants to produce $\mathrm{CO}_{2}$, $\mathrm{H}_{2} \mathrm{O}$, and other byproducts [10].

PFC using a series of $\mathrm{TiO}_{2}$ nanotubes (TNA) photoanode has been studied recently [2-3,11-13]. The properties of photoanode structures, such as specific surface area and thickness of photoanodes, can affect the ability to utilize light and inhibit transport of electrons produced under illumination [2-3,11,14]. Other researchers used $\mathrm{ZnO} / \mathrm{Zn}$ as photoanodes [15] with open and closed-circuit systems without supporting electrolytes. The presence of supporting electrolytes, however, can improve the PFC performance [1] by increasing the conductivity of the solution and reducing the internal resistance. Decreasing internal barriers results in greater potential differences in both electrodes and enhances the electrons flow at the cathode, leaving holes in the photoanode that have a strong oxidation property. 


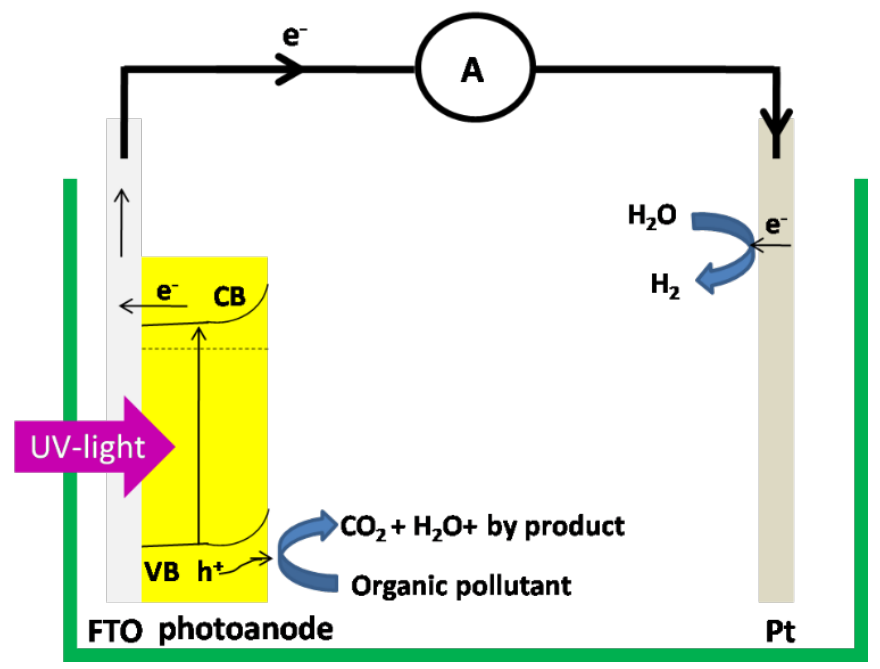

Fig 1. Illustration of organic pollutant degradation process using photofuel cell with photoanode under UVlight illumination. $\mathrm{CB}, \mathrm{VB}, \mathrm{h}^{+}$, and $\mathrm{e}^{-}$represent conduction band, valence band, hole, electron, respectively. Under the UV-light illumination, electrons are excited to the $\mathrm{CB}$ of $\mathrm{n}$-CdS, leaving holes at VB. The photogenerated electrons are then driven to FTO as back contact to an external circuit (the current flow is measured by Ampere meter) and return to a platinum electrode where they may reduce protons to molecular hydrogen. Meanwhile, the photogenerated holes will oxidize organic pollutants to produce $\mathrm{CO}_{2}, \mathrm{H}_{2} \mathrm{O}$, and byproducts

Therefore, most researchers use supporting electrolytes in PFC to improve the efficiency of degradation and generation of electricity from PFCs [16-18].

So far, there are limited studies of bare CdS thin film prepared by chemical bath deposition (CBD) in the PFC system, although it has potency as a photoanode due to its high absorption coefficient $\left(10^{4} \mathrm{~cm}^{-1}\right)$ and wide-bandgap. The previous researchers used $\mathrm{CdS}$ sandwiched with other photoanodes such as $\mathrm{ZnS}$ and $\mathrm{TiO}_{2}$ for PFC [19]. The CdS thin film is widely used as a buffer layer in solar cells [20-21] and photoelectrochemical water splitting [20,22-26). The CdS thin film can be prepared by electrochemical deposition [27] and chemical bath deposition [28-31]. In this study, CdS thin film was prepared by the CBD method and characterized by SEMEDX, XRD, Raman, UV-Vis absorption spectrophotometer as well as photocurrent test under illumination using potentiostat with the three-electrode system. Then, the CdS thin film was applied as a photoanode in the PFC system with electrolytes and an organic compound of methylene blue. The effects of other parameters such as open and closed-circuits, initial concentration, and $\mathrm{pH}$ from methylene blue degradation were also studied.

\section{- EXPERIMENTAL SECTION}

\section{Materials}

Aquadest was supplied from Batraco (Indonesia), nitrogen gas was supplied from Samator (Indonesia). Acetone, hydrochloric acid, cadmium sulfate, thiourea, ammonia, methylene blue, $\mathrm{Na}_{2} \mathrm{SO}_{4}, \mathrm{Na}_{2} \mathrm{SO}_{3}, \mathrm{NaOH}$ were pro-analytical grade and were purchased from Merck (Darmstadt, Germany).

\section{Procedure}

\section{Preparation of CdS thin film}

Preparation of working electrode. Fluorine-doped tin oxide (FTO)-coated glass $(1 \mathrm{~cm} \times 2 \mathrm{~cm})$ was used as a substrate for CdS thin film deposition. Before the deposition, the FTO glass substrates were cleaned with sequential sonication in acetone and distilled water for 10 min, then dried using $\mathrm{N}_{2}$ gas.

Deposition of CdS by chemical bath deposition (CBD). The deposition of CdS was similar to our previous work [22]. Typical FTO glass substrates were covered with sticky tape at half of the area (it was used as the contact of photoanode). Then, the uncovered areas were immersed in an aqueous solution containing $12.5 \mathrm{mM} \mathrm{CdSO}_{4}, 0.22 \mathrm{M}$ thiourea $\left(\mathrm{H}_{2} \mathrm{NCSNH}_{2}\right)$, and $11 \mathrm{M}$ ammonia at $60{ }^{\circ} \mathrm{C}$ for $7 \mathrm{~min}$. The film was then washed with demineralized water and dried using $\mathrm{N}_{2}$ gas. The area of single FTO covered with CdS as the working area of photoanode was $1 \mathrm{~cm} \times 1 \mathrm{~cm}$.

\section{Characterization}

Crystalline structures of the CdS film was analyzed by X-ray diffraction (XRD) using a PANalytical X Pert ${ }^{3}$ Powder X-ray diffractometer (Cu Ka, Ni filter). Raman spectrum was analyzed by a Jasco NRC 3100 Laser Raman Spectrophotometer with an excitation laser of the wavelength of $532 \mathrm{~nm}$. Morphologies of the films 
were examined using a JSM-6510LA Analytical SEM (scanning electron microscope) at an acceleration voltage of $20 \mathrm{kV}$. Atomic percentages were analyzed by SEM-EDX (Phenom Pro-X desktop SEM with EDX). Bandgap determination was done by the UV-Vis absorption spectrophotometer (Shimadzu series prestige 21). Photocurrent (J-V) test was conducted in $1 \mathrm{M} \mathrm{Na}_{2} \mathrm{SO}_{3}$ as hole scavenging using potentiostat-galvanostat (Electrochemical Workstation CorrTest CS Studio 150) under 1.5 AM solar simulation with a three-electrode system (CdS thin film, Ag/ $\mathrm{AgCl}$ electrode and Pt electrode as working, reference, and counter electrodes, respectively). The measurements were done from the potential of 1.0 to $-0.2 \mathrm{~V}$ (vs. $\mathrm{Ag} / \mathrm{AgCl}$ ) with a scan rate of $10 \mathrm{mV} / \mathrm{s}$.

\section{Application of CdS photoanode for degradation of methylene blue in photofuel cell (PFC)}

Methylene blue degradation was conducted using the equipment shown in Fig. 1. It consists of a photoanode and a platinum sheet $(2 \mathrm{~cm} \times 1 \mathrm{~cm})$ that is arranged and inserted into a reactor containing methylene blue as artificial waste. Next, irradiation was carried out using a 25 Watt UV lamp (365 nm) at a distance of $20 \mathrm{~cm}$ apart. The initial concentration of dyes $(100 \mathrm{mg} / \mathrm{L})$, the time of treatment, and the use of $0.1 \mathrm{M}$ electrolytes of $\mathrm{Na}_{2} \mathrm{SO}_{4}$, $\mathrm{HCl}$, and $\mathrm{NaOH}$ were evaluated. Concentrations of the dyes after treatment were carried out using a UV-Vis spectrophotometer by plotting the measured absorbance to the calibration curve (absorbance vs. concentration of methylene blue) at $662 \mathrm{~nm}$ as the maximum absorbance peak of methylene blue at the acidic and neutral condition. For alkaline condition maximum wavelength of methylene blue was c.a $620 \mathrm{~nm}$. Potential generated from the PFC was measured using a multimeter (SANWA).

\section{- RESULTS AND DISCUSSION}

The films obtained by this method were yellow, very compact, continuous, and adhere very well, as shown in Fig. 2. The classical mechanism of CdS growth using CBD can be summarized by the following chemical reactions [32]:

Complex formation of cadmium salt with ammonia:
$\mathrm{CdSO}_{4}+4 \mathrm{NH}_{3} \rightleftharpoons\left[\mathrm{Cd}\left(\mathrm{NH}_{3}\right)_{4}\right] \mathrm{SO}_{4}$

The formation of $\left[\mathrm{Cd}\left(\mathrm{NH}_{3}\right)_{4}\right] \mathrm{SO}_{4}$ prevents the precipitation of $\mathrm{Cd}(\mathrm{OH})_{2}$. The complex ions $\left[\mathrm{Cd}\left(\mathrm{NH}_{3}\right)_{4}\right]^{2+}, \mathrm{SO}_{4}{ }^{2-}, \mathrm{OH}^{-}$, and thiourea diffuse to the catalytic surface of the substrate

Hydrolysis of thiourea in an alkaline medium:

$\left(\mathrm{NH}_{2}\right)_{2} \mathrm{CS}+\mathrm{OH}^{-} \rightleftharpoons \mathrm{HS}^{-}+\mathrm{CH}_{2} \mathrm{~N}_{2}+\mathrm{H}_{2} \mathrm{O}$

where $\mathrm{HS}^{-}$ions are in equilibrium with water and give $\mathrm{S}^{2-}$ ions according to this equation:

$\mathrm{SH}^{-}+\mathrm{OH}^{-} \rightleftharpoons \mathrm{S}^{2-}+\mathrm{H}_{2} \mathrm{O}$

Cadmium sulfide formation:

$\left[\mathrm{Cd}\left(\mathrm{NH}_{3}\right)_{4}\right]^{2+}+\mathrm{S}^{2-} \rightarrow \mathrm{CdS}+4 \mathrm{NH}_{3}$

\section{EDX Analysis of CdS Thin Film}

The atomic percentage of CdS on the FTO glass was shown in Table 1. It shows that there are six elements from EDX results, namely tin, calcium, cadmium, sulfur, oxygen, and silicon. The dominant elements are tin, cadmium, and oxygen. The tin comes from the FTO constituent, namely fluorinated tin oxide, while the calcium and silicon were derived from the glass materials. From these observations, it can be seen that the CdS composition is not 1:1, but $\mathrm{Cd}$ rich. This deviation

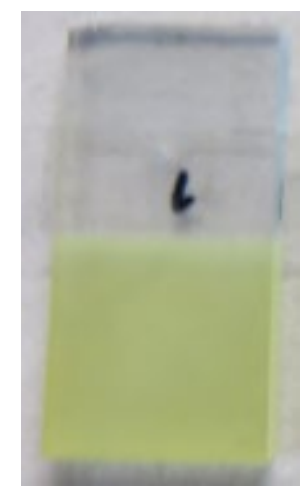

Fig 2. The thin film of CdS deposited by CBD

Table 1. Atomic percentages of CdS on FTO

\begin{tabular}{clc}
\hline Element symbol & Element name & Percentage (\%) \\
\hline $\mathrm{Sn}$ & Tin & 60.8 \\
$\mathrm{Ca}$ & Calcium & 0.4 \\
$\mathrm{Cd}$ & Cadmium & 17.9 \\
$\mathrm{~S}$ & Sulfur & 3.3 \\
$\mathrm{O}$ & Oxygen & 17.0 \\
$\mathrm{Si}$ & Silicon & 0.6 \\
\hline
\end{tabular}


could be due to the presence of oxygen that comes from the atmosphere or the solution used for the chemical bath deposition of CdS. Here, the ammonia that is used as the alkaline condition can affect the $\mathrm{OH}^{-}$ions and the possibility of inclusion of oxygen in the deposition process. As a result, it will cause a higher percentage of oxygen in the thin film [33].

\section{XRD Analysis}

The XRD peaks of CdS thin film are depicted in Fig. 3. The peaks at $2 \theta=34.29^{\circ}, 38.32^{\circ}$, and $62.15^{\circ}$ are the peaks of $\mathrm{SnO}_{2}$ coming from the substrate used (FTO). Other diffractions in the XRD pattern are observed at $2 \theta$ $=27.05^{\circ}, 52^{\circ}, 66^{\circ}$, and $78.88^{\circ}$, attributable to the reflection of CdS at ( ( $\left.\begin{array}{lll}0 & 2\end{array}\right),\left(\begin{array}{lll}1 & 1 & 2\end{array}\right),\left(\begin{array}{lll}2 & 0 & 3\end{array}\right)$, and (2 044$)$ which have hexagonal crystal structure, with lattice parameters $\mathrm{a}=$ $4.157 \AA ̊$ and $c=6.580 \AA \AA$ (JCPDS card no. 41-1049) [34]. Some small peaks are observed at $2 \theta=29.84^{\circ}$ and $44.80^{\circ}$, corresponds to the reflection of CdS ( $\left(\begin{array}{lll}2 & 0 & 0\end{array}\right)$ and $\left(\begin{array}{lll}2 & 0 & 0\end{array}\right)$ from the CdS cube (JCPDS card no. 80-0019) [35]. The average crystallite size $(\mathrm{nm})$ measured using Scherrer's formula [33] was found to be $30.13 \mathrm{~nm}$. The Scherrer's formula is written as:

$\mathrm{D}=\mathrm{k} \cdot \lambda /(\beta \cdot \cos \theta)$

where $\mathrm{k}$ is a constant of $0.94, \lambda$ is the wavelength of $\mathrm{X}$-ray source (in this case, $\mathrm{Cu}-\mathrm{K} \alpha$ is $0.15406 \mathrm{~nm}$ ), $\beta$ is the full width at half the peak maximum (radians), and $\theta$ is Bragg's angle.

From the XRD study, it can be seen that the CdS is a mixture of cube and hexagonal phase that is a characteristic of the film prepared by the CBD method and also in a good agreement with the previous report for CdS thin layer [33].

\section{SEM Analysis}

Fig. 4 shows the SEM image of CdS on FTO at 20,000 magnifications. It can be seen that the FTO substrate was covered well without a small crack or hole. This SEM proves that the film is uniform and homogeneous. The thin film sample has a morphology of platelets-like nanocrystalline CdS with a size of less than $1 \mu \mathrm{m}$.

\section{Raman Analysis}

Raman spectroscopy can be used to characterize the

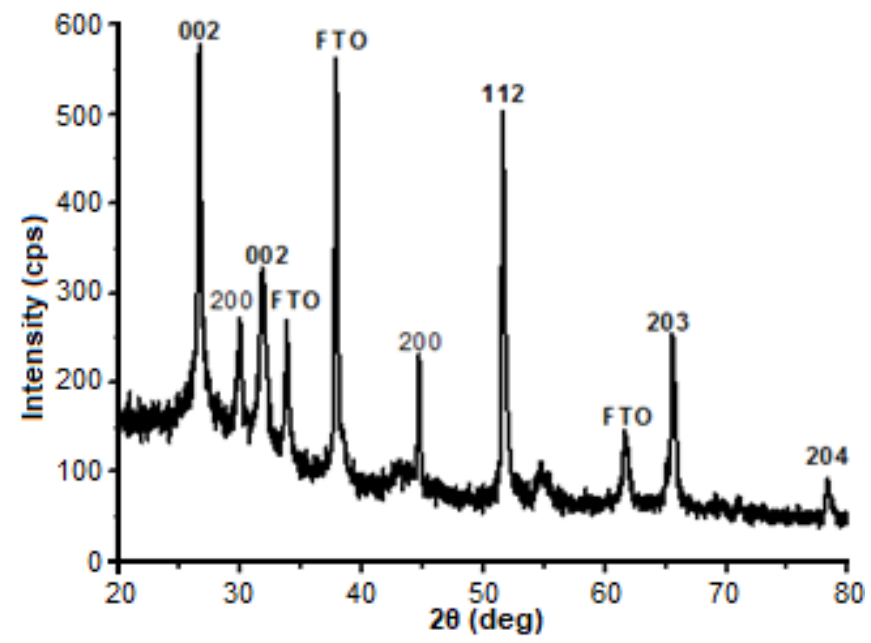

Fig 3. XRD of CdS thin film on FTO

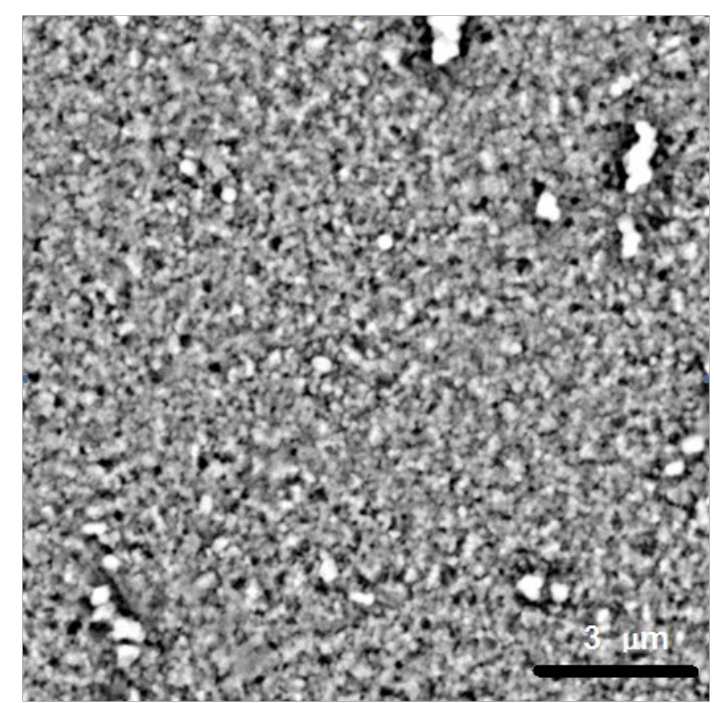

Fig 4. SEM image of CdS on FTO with 20,000 magnification

crystalline behavior of the material quality, including the surface condition and homogeneity with fast and nondestructive work, with a sharp peak for the crystalline sample and very broad peaks for amorphous or polycrystalline ones [36]. Hence, Raman spectroscopy was used for the structural characterization of CdS thin film. Fig. 5 shows the typical Raman spectrum of CdS thin film prepared by chemical bath deposition. The spectrum shows the presence of peaks at 295 and $595 \mathrm{~cm}^{-1}$, which are typical wavenumber regions for $\mathrm{CdS}$ crystals of hexagonal wurtzite. This result is in good agreement with the previous work [36] that reported the sharp peaks at 295 and $592 \mathrm{~cm}^{-1}$ with a different route of 


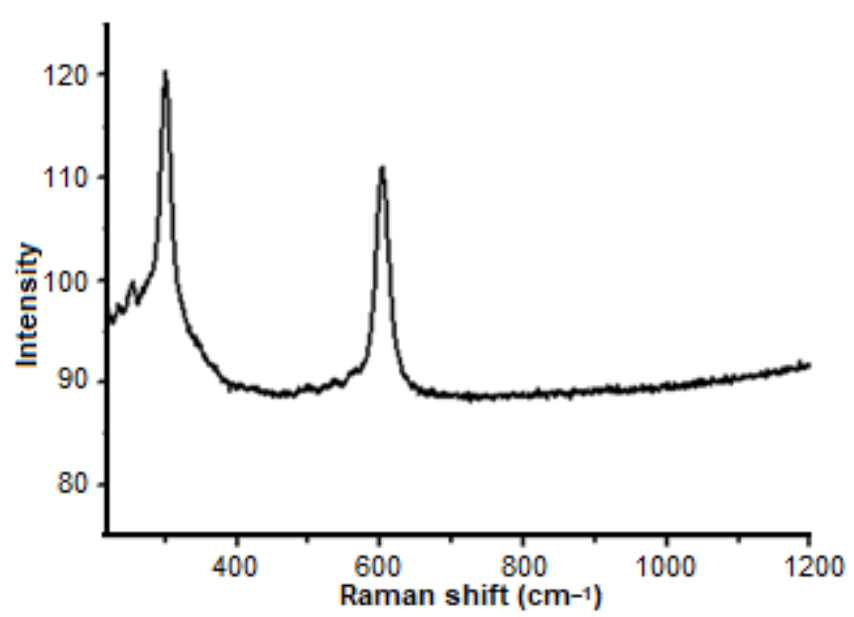

Fig 5. Raman spectrum of CdS on FTO

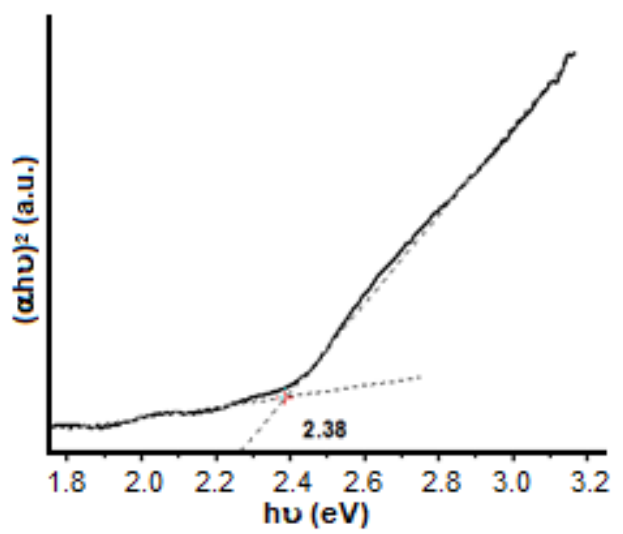

Fig 6. Graph of $(\alpha h v)^{2}$ correlation with hv for direct optical transition of CdS

CdS growth. A slight shift to 303.5 and $593.0 \mathrm{~cm}^{-1}$ that corresponds to the values with the first and second harmonic modes in the Raman spectrum was observed from the CdS sample prepared by the solvothermal process [37].

\section{Bandgap}

Determination of the bandgap $\left(\mathrm{E}_{\mathrm{g}}\right)$ of a synthesized semiconductor is important on behalf of sunlight irradiation harvesting at an appropriate wavelength region (ultraviolet, visible, or infrared). From the previous study, CdS as an $n$-type semiconductor has a wider bandgap (close to UV region) than a p-type semiconductor. Therefore, CdS is usually used as a buffer layer in a solar cell or photoelectrochemical water splitting [20-26].
The bandgap value of CdS is determined by the Tauc graph expressed in the following equation:

$(\alpha h v)^{\mathrm{n}}=\mathrm{A}\left(\mathrm{h} v-\mathrm{E}_{\mathrm{g}}\right)$

The magnitude $\alpha$ is the absorption coefficient, hu is the energy of the incoming photon, $A$ is a constant, and $n$ varies from 0.5 to 2.0 depending on the optical transition properties. For the CdS thin layer, a straight line for the plot $(\alpha h v)^{2}$ (that is, $n=2$ ) is obtained, suggesting the direct band character of the film. Fig. 6 shows the Tauc plot for the determination of the bandgap of the CdS thin layer. The bandgap is obtained to be $2.38 \mathrm{eV}$ for $\mathrm{CdS}$ prepared by the CBD method, deposited for $7 \mathrm{~min}$. The wavelength of $520.6 \mathrm{~nm}$ was obtained by converting the bandgap using equation $\lambda=1240 / \mathrm{E}_{\mathrm{g}}$. It indicates that the $\mathrm{CdS}$ thin film semiconductor will work effectively below $520.6 \mathrm{~nm}$.

\section{Photocurrent Measurement}

The photo-voltammetry technique offers a powerful method to evaluate the photoactivity of semiconductors. The measurement is conducted by sweeping the electrode potential under chopped light. White light or LED light with the wavelengths where the semiconductor absorbs strongly is commonly used as the light source. The fraction of photogenerated minority carriers contributing to the photocurrent is shown by the magnitude of the photocurrent. Hence, it shows the existence of surface or bulk traps, and also indicates the external quantum efficiency (EQE). Information of the pinholes in the film or any impurities in the film is indicated by scanning in the dark (light off), which can be deduced from the high dark currents and the appearance of transient current spikes associated with oxidation and reduction of redox couple in contact with the metal substrate or impurities [38].

Fig. 7 shows the voltammogram of CdS thin film measured using $\mathrm{Na}_{2} \mathrm{SO}_{3}$ solution as hole scavenging measured under chopped illumination of sunlight simulation irradiation at 1.5 AM. It shows that the CdS film has an $n$-type semiconductor property, as observed by the positive photocurrent. The photocurrent at $1.0 \mathrm{~V}$ (vs. $\mathrm{Ag} / \mathrm{AgCl}$ ) is c.a. $0.04 \mathrm{~mA} / \mathrm{cm}^{2}$. This value is higher 


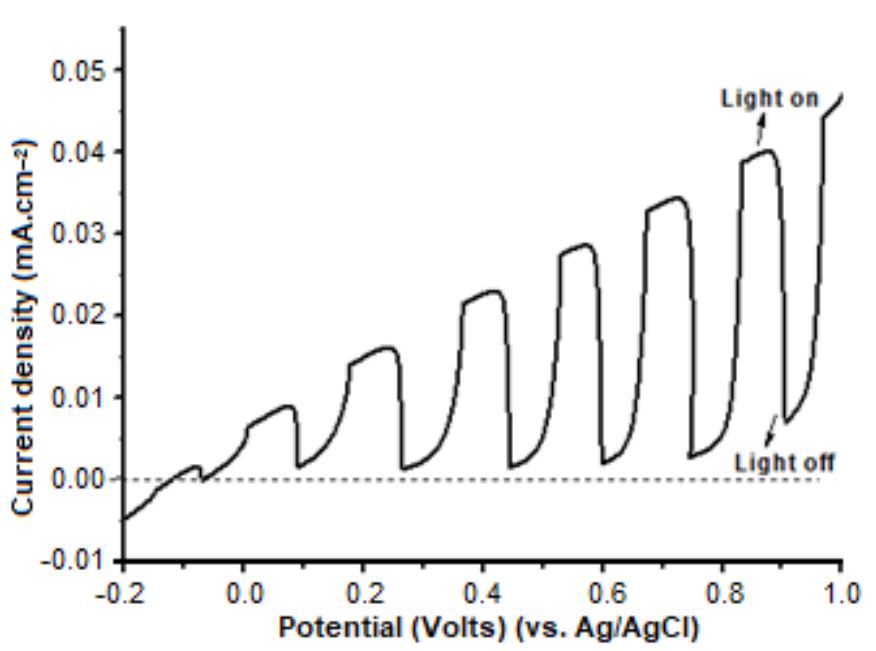

Fig 7. Potential and photocurrent curve of CdS thin film $(2 \mathrm{~cm} \times 2 \mathrm{~cm})$ measured in $0.1 \mathrm{M} \mathrm{Na}_{2} \mathrm{SO}_{3}$ in three-electrode systems with chopped irradiation of $1.5 \mathrm{AM}$ solar simulator

than the previous work [39]. The photocurrent response shows the quality of the thin-film semiconductor. The higher the photocurrent, the higher the impact to produce hole and electron when the semiconductor is illuminated. Consequently, it will produce more effective dye degradation.

\section{Application of CdS Thin Film Photoanode for Degradation of Methylene Blue in Photofuel Cell (PFC)}

Fig. 8 shows the percentage of methylene blue (MB) decrease at various times of light exposure. It shows that there is a significant decrease in MB degradation until the time of 90 min of UV light exposure. However, there is a minor decrease of $\mathrm{MB}$ after $90 \mathrm{~min}$, possibly due to the photocathode coverage by MB that hinders the passage of light for the commences of the photoelectrochemical process. The degradation of $\mathrm{MB}$ at $150 \mathrm{~min}$ is around $1.06 \mathrm{mg}$ (50 mL MB $100 \mathrm{mg} / \mathrm{L})$. Concerning our previous work [22], the thickness of CdS is c.a. $100 \mathrm{~nm}$, and the density of CdS is $4.82 \mathrm{~g} / \mathrm{cm}^{3}$ so that the mass of CdS thin film is $48.2 \mathrm{ug}$. Finally, the effectiveness of CdS thin film as a photoanode to degrade $\mathrm{MB}$ is around 1: 51,000 (or $1 \mathrm{mg}$ of CdS thin film can convert $51,000 \mathrm{mg}$ or $51 \mathrm{~g}$ of $\mathrm{MB}$ ).

The effect of electrolytes on the destruction process of MB using PFC with photoanode was also investigated. MB degradation with various additional electrolytes after CdS treatment, either with or without bias, for $\mathrm{CdS}$ photoanodes with the areas of both $1 \times 1 \mathrm{~cm}^{2}$ and $2 \times$ $2 \mathrm{~cm}^{2}$ is given in Fig. 9.

The addition of electrolytes increased the methylene blue degradation process. This phenomenon is due to the increase in the conductivity of the solution. However, the lowest degradation was obtained from the use of sodium sulfate, followed by $\mathrm{HCl}$ and $\mathrm{NaOH}$. Since sodium sulfate functions merely as an electrolyte that improves conductivity, there is no reaction occurs at anode and cathode. Meanwhile, for $\mathrm{HCl}$ and $\mathrm{NaOH}$, their anions will enhance the degradation of MB. Chloride ions will be oxidized at the anode to form chlorine that is a strong oxidant to degrade MB. The effect will be even more significant when $\mathrm{NaOH}$ is used as the electrolyte due to the formation of ${ }^{*} \mathrm{OH}$ radical (from hydroxide ions) and hole of CdS semiconductor when illuminated. The radical is a powerful oxidant for the destruction of MB. The mechanisms occur during CdS irradiation with UV light as follows [40]:

$$
\begin{aligned}
& \mathrm{CdS}+\mathrm{hu}(\mathrm{UV}) \rightarrow \mathrm{CdS}\left(\mathrm{e}_{\mathrm{CB}}{ }^{-}+\mathrm{h}_{\mathrm{VB}}{ }^{+}\right) \\
& \mathrm{CdS}\left(\mathrm{h}_{\mathrm{VB}}{ }^{+}\right)+\mathrm{H}_{2} \mathrm{O} \rightarrow \mathrm{CdS}+\mathrm{H}^{+}+\mathrm{OH}^{-} \\
& \mathrm{CdS}\left(\mathrm{h}_{\mathrm{VB}}{ }^{+}\right)+\mathrm{OH}^{-} \rightarrow \mathrm{CdS}+\mathrm{OH}^{*} \\
& \text { Dye }+\mathrm{OH}^{*} \rightarrow \text { deg radation product }
\end{aligned}
$$

$\mathrm{OH}^{\star}$ radical will increase with the increase of $\mathrm{pH}$ (alkaline solution). Therefore, it has more effect on dye degradation at high $\mathrm{pH}$ solution.

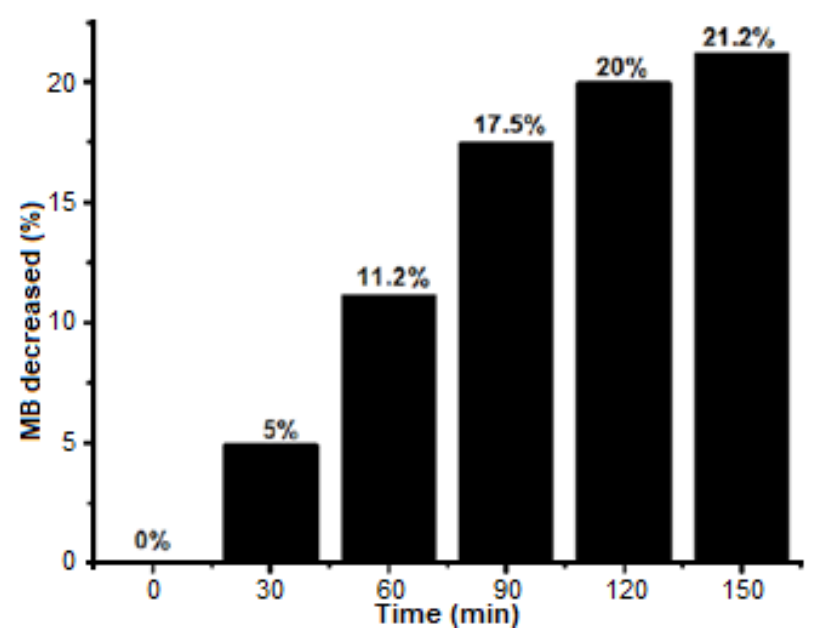

Fig 8. $M B$ decrease calculated at the maximum wavelength $(662 \mathrm{~nm})$ when treated by CdS photoanode in $\mathrm{PFC}$ with $\mathrm{Na}_{2} \mathrm{SO}_{4}$ electrolyte at various times of light exposure with the bias of $0.5 \mathrm{~V}$ 


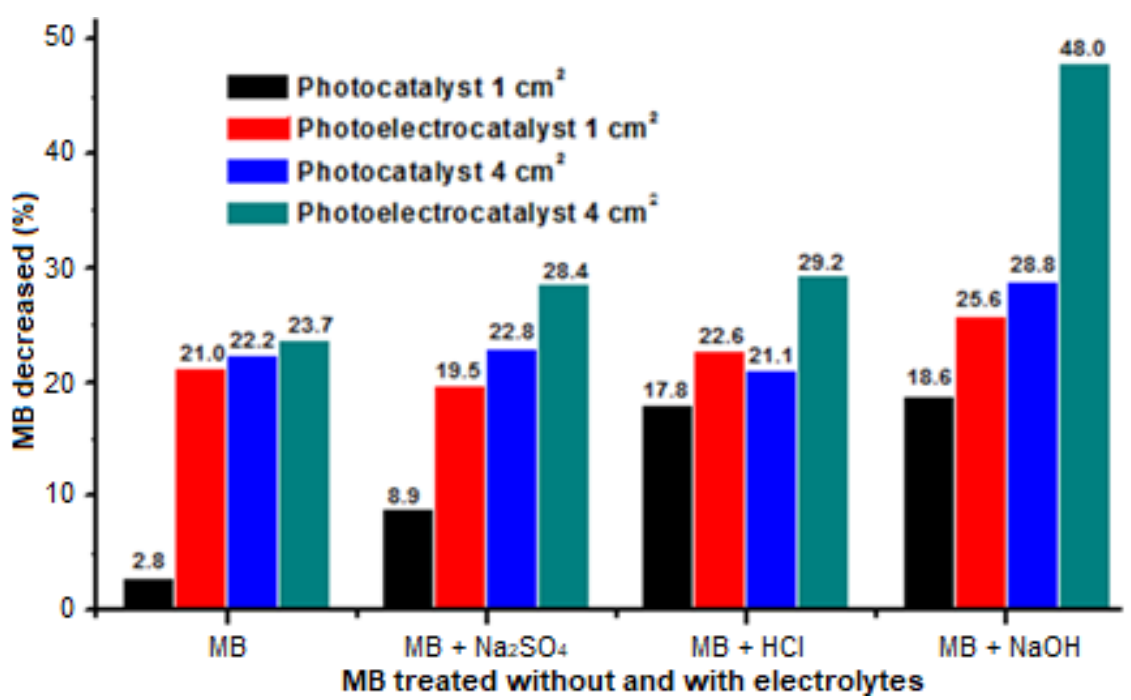

Fig 9. Graph of methylene blue (MB) degradation with and without electrolytes using photoanode areas of $1 \mathrm{~cm} \times 1 \mathrm{~cm}$ and $2 \mathrm{~cm} \times 2 \mathrm{~cm}$, both for PFC with and without bias

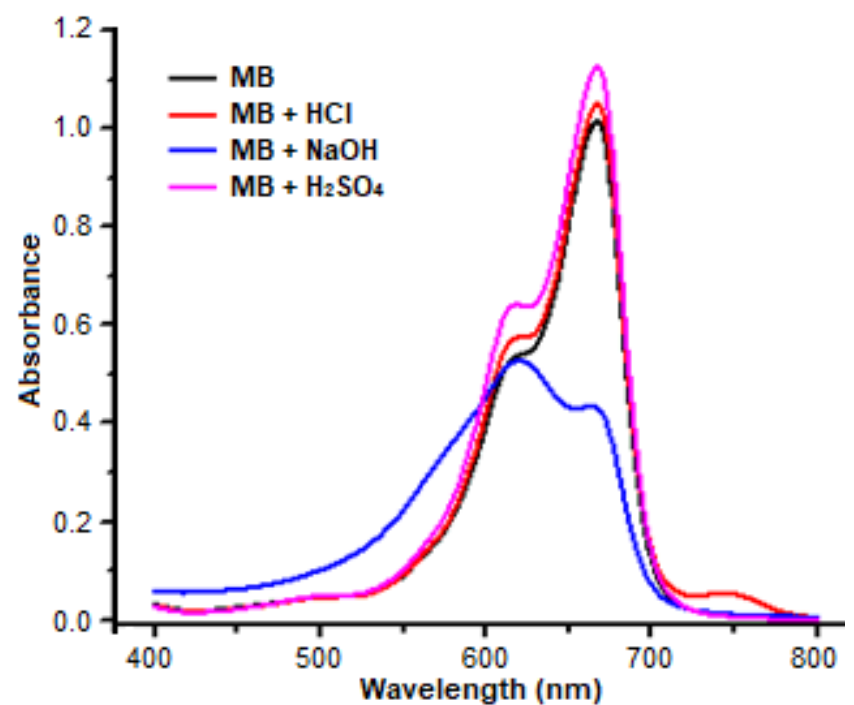

Fig 10. The absorption spectra of methylene blue solution $\mathrm{Cl}^{-}$with and without electrolytes

Meanwhile, bias potential from the external source enhanced the photodegradation process because of the increase in the generated electron and hole by external potential. The larger area of the photoanode also increases MB degradation. An increase in the CdS working area from 1 to $4 \mathrm{~cm}^{2}$ on the sample with $\mathrm{NaOH}$ electrolytes resulted in the improvement of the MB degradation up to twice larger. Since the current produced at the photoanode was enhanced with the use of a wider area, the degradation of MB will also increase.
The possibility of $\mathrm{MB}$ degradation at different $\mathrm{pH}$ was also evaluated. The use of $\mathrm{HCl}$ and $\mathrm{NaOH}$ at the concentration of $0.1 \mathrm{M}$ was found not to degrade the $\mathrm{MB}$ (data not shown). However, they only change the visible light absorption spectra of the methylene blue with and without the addition of the electrolyte (Fig. 10). The maximum peak is different for methylene blue in alkaline solution compare to the other electrolytes. The changes in $\mathrm{pH}$ do not degrade the dye (data not shown) but might shift the maximum peak. Therefore, for alkaline conditions, the maximum peak near $600 \mathrm{~nm}$ was used to determine the concentration of photodegradation MB.

The intermediates resulted from the degradation process were investigated by using GC-MS and LC-MS, identified by the commercially standard comparison and mass spectra for interpretation of their fragment ions. Fig. 11 shows the methylene blue degradation pathways in detail. The final products of the CdS photoanode of $\mathrm{PFC}$ are the almost completed mineralization of carbon, nitrogen, and sulfur heteroatoms into $\mathrm{CO}_{2}, \mathrm{NH}_{4}{ }^{+}, \mathrm{NO}_{3}{ }^{-}$, and $\mathrm{SO}_{4}{ }^{2-}$, respectively [41].

The open-circuit potential $\left(\mathrm{V}_{\text {oc }}\right)$ of the PFC system is a potential measured using voltmeter without load from the photoelectrochemical cell consists of photoanode, MB either with and without electrolytes, and 


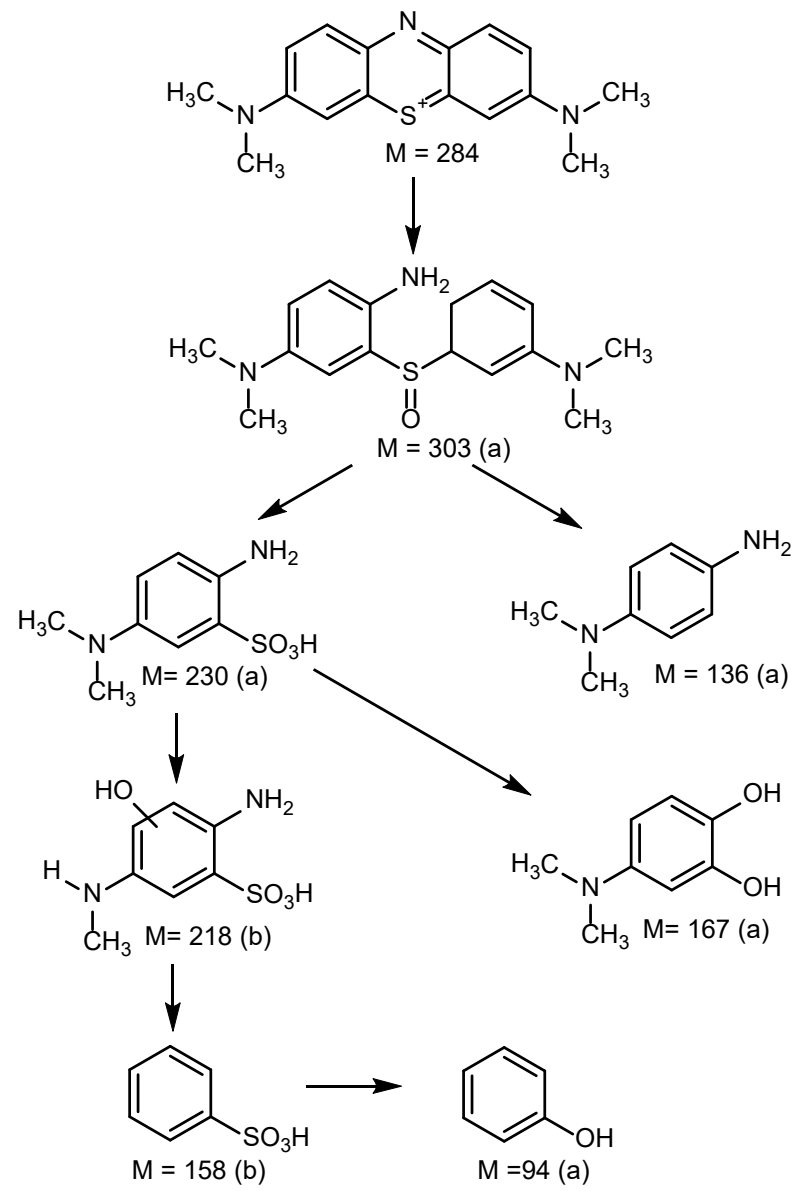

Fig 11. Photocatalytic degradation pathway of MB [41]

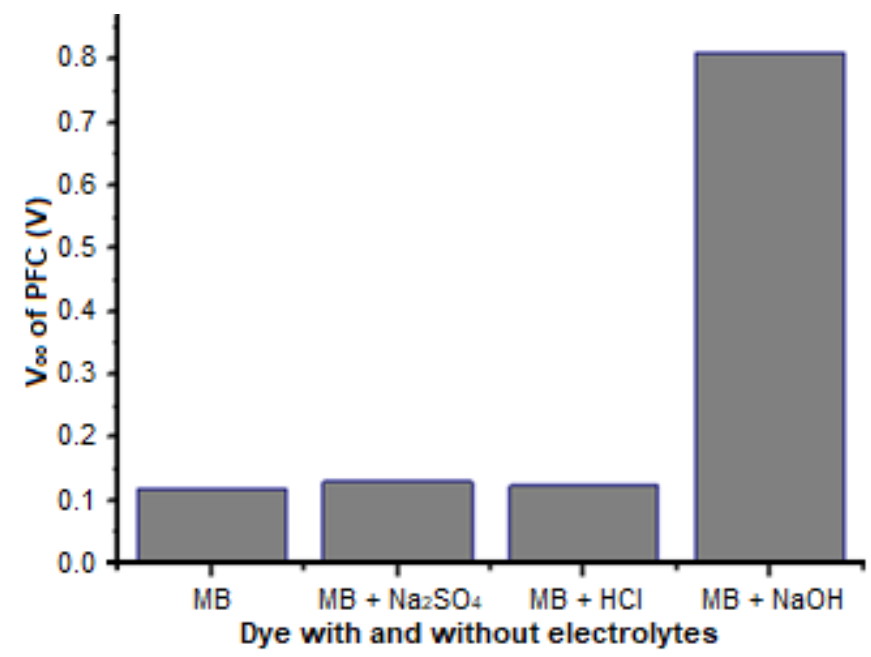

Fig 12. Open-circuit potential of measured PFC system consisting of methylene blue $100 \mathrm{mg} / \mathrm{L}$ with and without electrolytes, CdS photoanode, and platinum cathode

platinum as cathode under UV light irradiation. The generated voltage can be seen in Fig. 12. It shows that $V_{o c}$ is c.a. $0.1 \mathrm{~V}$ for $100 \mathrm{mg} / \mathrm{L} \mathrm{MB}$, both without electrolytes and with the addition of $\mathrm{Na}_{2} \mathrm{SO}_{4}$ and $\mathrm{HCl}$. The $\mathrm{V}_{\text {oc }}$ increases up to c.a. $0.8 \mathrm{~V}$ when using $\mathrm{NaOH}$. The low $\mathrm{V}_{\text {oc }}$ can be attributable to the slow degradation of the $\mathrm{MB}$ process in $\mathrm{HCl}$ and $\mathrm{Na}_{2} \mathrm{SO}_{4}$ due to the small amount of the produced $\mathrm{OH}^{\star}$ radical. In the system with $\mathrm{NaOH}$, the higher $\mathrm{V}_{\text {oc }}$ is probably due to the vigorous process with many productions of $\mathrm{OH}^{*}$ radical. The results are in accordance with previous reports [42], even though the $\mathrm{V}_{\text {oc }}$ was found to be a little higher in acidic solution using $\mathrm{MB}$ as the fuel due to the use of non-platinum based photocathode. The easiness of the hole to react with the fuel, such as methanol, can also improve the $\mathrm{V}_{\text {oc }}$ [43].

\section{- CONCLUSION}

The CdS synthesis had been successfully carried out using the Chemical Bath Deposition (CBD) method. Characterization with EDX obtained the CdS composition in the $\mathrm{Cd}$ rich composition. Analysis using SEM shows the presence of nanocrystals measuring less than $1 \mu \mathrm{m}$ and thin films evenly and covering the FTO substrate. XRD shows the presence of CdS crystals in the cube and hexagonal formations. Typical of CdS characteristic was also observed using a Raman Spectrophotometer. The bandgap of CdS was obtained to be $2.38 \mathrm{eV}$. The photocurrent test shows that $\mathrm{CdS}$ has $n$-type semiconductor property with a photocurrent of c.a. $0.04 \mathrm{~mA} / \mathrm{cm}^{2}$ at a potential of $1.0 \mathrm{~V}$ (vs. $\mathrm{Ag} / \mathrm{AgCl}$ ). Application of $\mathrm{CdS}$ as photoanodes in the photoelectrocatalytic system for methylene blue treatments showed degradation up to $48 \%$ for $100 \mathrm{mg} / \mathrm{L}$ samples within $2.5 \mathrm{~h}$ using a $4 \mathrm{~cm}^{2}$ photoanode. The measurement of the voltage from the PFC was obtained from 0.1 to $0.8 \mathrm{~V}$ for a PFC system with a $1 \mathrm{~cm}^{2}$ photoanode area with $100 \mathrm{mg} / \mathrm{L} \mathrm{MB}$.

\section{- ACKNOWLEDGMENTS}

The authors are thankful to the Faculty of Science and Mathematics at Diponegoro University for supporting this work.

\section{- REFERENCES}

[1] Antoniadou, M., Kondarides, D.I., Labou, D., Neophytides, S., and Lianos, P., 2010, An efficient 
photoelectrochemical cell functioning in the presence of organic wastes, Sol. Energy Mater. Sol. Cells, 94 (3), 592-597.

[2] Li, J., Li, J., Chen, Q., Bai, J., and Zhou, B., 2013, Converting hazardous organics into clean energy using a solar responsive dual photoelectrode photocatalytic fuel cell, J. Hazard. Mater., 262, 304310.

[3] Li, K., Xu, Y., He, Y., Yang, C., Wang, Y., and Jia, J., 2013, Photocatalytic fuel cell (PFC) and dye selfphotosensitization photocatalytic fuel cell (DSPFC) with $\mathrm{BiOCl} / \mathrm{Ti}$ photoanode under UV and visible light irradiation, Environ. Sci. Technol., 47 (7), 34903497.

[4] Xia, L., Bai, J., Li, J., Zeng, Q., Li, X., and Zhou, B., 2016, A highly efficient $\quad \mathrm{BiVO}_{4} / \mathrm{WO}_{3} / \mathrm{W}$ heterojunction photoanode for visible-light responsive dual photoelectrode photocatalytic fuel cell, Appl. Catal., B, 183, 224-230.

[5] Ogura, Y., Okamoto, S., Itoi, T., Fujishima, Y., Yoshida, Y., and Izumi, Y., 2014, A photofuel cell comprising titanium oxide and silver (I/0) photocatalysts for use of acidic water as a fuel, Chem. Commun., 50 (23), 3067-3070.

[6] Iyatani, K., Horiuchi, Y., Fukumoto, S., Takeuchi, M., Anpo, M., and Matsuoka, M., 2013, Separate-type Ptfree photofuel cell based on a visible light-responsive $\mathrm{TiO}_{2}$ photoanode: Effect of hydrofluoric acid treatment of the photoanode, Appl. Catal., A, 458, 162-168.

[7] Fujiwara, K., Akita, A., Kawano, S., Fujishima, M., and Tada, H., 2017, Hydrogen peroxide-photofuel cell using $\mathrm{TiO}_{2}$ photoanode, Electrochem. Commun., 84, 71-74.

[8] Seger, B., Lu, G.Q., and Wang, L., 2012, Electrical power and hydrogen production from a photo-fuel cell using formic acid and other single-carbon organics, J. Mater. Chem., 22 (21), 10709-10715.

[9] Fujishima, Y., Okamoto, S., Yoshiba, M., Itoi, T., Kawamura, S., Yoshida, Y., Ogura, Y., and Izumi, Y., 2015, Photofuel cell comprising titanium oxide and bismuth oxychloride $\left(\mathrm{BiO}_{1-\mathrm{x}} \mathrm{Cl}_{1-\mathrm{y}}\right)$ photocatalysts that uses acidic water as a fuel, J. Mater. Chem. A, 3 (16), 8389-8404.

[10] Konstantinou, I.K., and Albanis, T.A., 2004, $\mathrm{TiO}_{2-}$ assisted photocatalytic degradation of azo dyes in aqueous solution: kinetic and mechanistic investigations: A review, Appl. Catal., B, 49 (1), 1-14.

[11] Liu, Y., Zhou, B., Li, J., Gan, X., Bai, J., and Cai, W., 2009, Preparation of short, robust and highly ordered $\mathrm{TiO}_{2}$ nanotube arrays and their applications as electrode, Appl. Catal., B, 92 (3-4), 326-332.

[12] Liu, Y., Li, J., Zhou, B., Chen, H., Wang, Z., and Cai, W., 2011, A $\quad \mathrm{TiO}_{2}$-nanotube-array-based photocatalytic fuel cell using refractory organic compounds as substrates for electricity generation, Chem. Commun., 47 (37), 10314-10316.

[13] Liu, Y., Li, J., Zhou, B., Li, X., Chen, H., Chen, Q., Wang, Z., Li, L., Wang, J., and Cai, W., 2011, Efficient electricity production and simultaneously wastewater treatment via a high-performance photocatalytic fuel cell, Water Res., 45 (13), 39913998.

[14] Liu, Y., Zhou, B., Bai, J., Li, J., Zhang, J., Zheng, Q., Zhu, X., and Cai, W., 2009, Efficient photochemical water splitting and organic pollutant degradation by highly ordered $\mathrm{TiO}_{2}$ nanopore arrays, Appl. Catal., B, 89 (1-2), 142-148.

[15] Lee, S.L., Ho, I.N., Ong, S.A., Wong, Y.S., Voon, C.H., Khalik, W.F., Yusoff, N.A., and Nordin, N., 2017, A highly efficient immobilized $\mathrm{ZnO} / \mathrm{Zn}$ photoanode for degradation of azo dye Reactive Green 19 in a photocatalytic fuel cell, Chemosphere, $166,118-125$.

[16] Wang, B., Zhang, H., Lu, X.Y., Xuan, J., and Leung, M.K.H., 2014, Solar photocatalytic fuel cell using $\mathrm{CdS}-\mathrm{TiO}_{2}$ photoanode and air-breathing cathode for wastewater treatment and simultaneous electricity production, Chem. Eng. J., 253, 174-182.

[17] Yang, J., Liao, W., Liu, Y., Muruganathan, M., and Zhang, Y., 2014, Degradation of rhodamine B using a visible-light driven photocatalytic fuel cell, Electrochim. Acta, 144, 7-15. 
[18] Li, L., Xue, S., Chen, R., Liao, Q., Zhu, X., Wang, Z., He, X., Feng, H., and Cheng, X., 2015, Performance characteristics of a membraneless solar responsive photocatalytic fuel cell with an air-breathing cathode under different fuels and electrolytes and air conditions, Electrochim. Acta, 182, 280-288.

[19] Antoniadou, M., Daskalaki, V.M., Balis, N., Kondarides, D.I., Kordulis, C., and Lianos, P., 2011, Photocatalysis and photoelectrocatalysis using (CdS$\mathrm{ZnS}) / \mathrm{TiO}_{2}$ combined photocatalysts, Appl. Catal., $B$, 107 (1-2), 188-196.

[20] Ikeda, S., Nonogaki, M., Septina, W., Gunawan, G., Harada, T., and Matsumura, M., 2013, Fabrication of $\mathrm{CuInS}_{2}$ and $\mathrm{Cu}(\mathrm{In}, \mathrm{Ga}) \mathrm{S}_{2}$ thin films by a facile spray pyrolysis and their photovoltaic and photoelectrochemical properties, Catal. Sci. Technol., 3 (7), 1849-1854.

[21] Jiang, F., Ozaki, C., Gunawan, Harada, T., Tang, Z., Minemoto, T., Nose, Y., and Ikeda, S., 2016, Effect of indium doping on surface optoelectrical properties of $\mathrm{Cu}_{2} \mathrm{ZnSnS}_{4}$ photoabsorber and interfacial/photovoltaic performance of cadmium free $\mathrm{In}_{2} \mathrm{~S}_{3} / \mathrm{Cu}_{2} \mathrm{ZnSnS}{ }_{4}$ heterojunction thin film solar cell, Chem. Matter., 28 (10), 3283-3291.

[22] Gunawan, G., Septina, W., Ikeda, S., Harada, T., Minegishi, T., Domen, K., and Matsumura, M., 2014, Platinum and indium sulfide-modified $\mathrm{CuInS}_{2}$ as efficient photocathodes for photoelectrochemical water splitting, Chem. Commun., 50 (64), 8941-8943.

[23] Zhao, J., Menigishi, T., Zhang, L., Zhong, M., Gunawan, Nakabyashi, M., Ma, G., Hisatomi, T., Kayatama, M., Ikeda, S., Shibata, N., Yamada, T., and Domen, K., 2014, Enhancement of solar hydrogen evolution from water by surface modification with CdS and $\mathrm{TiO}_{2}$ on porous CuInS 2 photocathodes prepared by an electrodeposition-sulfurization method, Angew. Chem. Int. Ed., 53 (44), 1180811812.

[24] Gunawan, Septina, W., Harada, T., Nose, Y., and Ikeda, S., 2015, Investigation of the electric structures of heterointerfaces in Pt- and $\operatorname{In}_{2} \mathrm{~S}_{3}$-modified $\mathrm{CuInS}_{2}$ photocathodes used for sunlight-induced hydrogen evolution, ACS Appl. Mater. Interfaces, 7 (29), 16086-16092.

[25] Septina, W., Gunawan, Ikeda, S., Harada, T., Higashi, M., Abe, R., and Matsumura, M., 2015, Photosplitting of water from wide-gap $\mathrm{Cu}(\mathrm{In}, \mathrm{Ga}) \mathrm{S}_{2}$ thin films modified with a CdS layer and $\mathrm{Pt}$ nanoparticles for a high-onset-potential photocathode, J. Phys. Chem. C, 119 (16), 85768583.

[26] Jiang, F., Gunawan, Harada, T., Kuang, Y., Minegishi, T., Domen, K., and Ikeda, S., 2015, $\mathrm{Pt} / \mathrm{In}_{2} \mathrm{~S}_{3} / \mathrm{CdS} / \mathrm{Cu}_{2} \mathrm{ZnSnS}_{4}$ thin film as an efficient and stable photocathode for water reduction under sunlight radiation, J. Am. Chem. Soc., 137 (42), 13691-13697.

[27] Zarębska, K., and Skompska, M., 2011, Electrodeposition of CdS from acidic aqueous thiosulfate solution-Investigation of the mechanism by electrochemical quartz microbalance technique, Electrochim. Acta, 56 (16), 5731-5739.

[28] Patil, B.N., Naik, D.B., and Shrivastava, V.S., 2011, Synthesis and characterization of Al doped CdS thin films grown by chemical bath deposition method and its application to remove dye by photocatalytic treatment, Chalcogenide Lett., 8 (2), 117-121.

[29] Zyoud, A., Saa'deddin, I., Khudruj, S., Hawash, Z.M., Park, D., Campet, G., and Hilal, H.S., 2013, CdS/FTO thin film electrodes deposited by chemical bath deposition and by electrochemical deposition: a comparative assessment of photoelectrochemical characteristics, Solid State Sci., 18, 83-90.

[30] Mir, F.A., Chattarjee, I., Dar, A.A., Asokan, K., and Bhat, G.M., 2015, Preparation and characterizations of cadmium sulfide nanoparticles, Optik, 126 (11-12), 1240-1244.

[31] Dumbrava, A., Badea, C., Prodan, G., and Ciupina, V., 2010, Synthesis and characterization of cadmium sulphide obtained at room temperature, Chalcogenide Lett., 7 (2), 111-118. 
[32] Rami, M., Benamar, E., Fahoume, M., Chraibi, F., and Ennaoui, A., 1999, Effect of the cadmium ion source on the structural and optical properties of chemical bath deposited CdS thin films, Solid State Sci., 1 (4), 179-188.

[33] Barote, M.A., Yadav, A.A., and Masumdar, E.U., 2011, Synthesis, characterization and photoelectrochemical properties of $\mathrm{n}$-CdS thin films, Physica B, 406 (10), 1865-1871.

[34] Yang, F., Tian, X., Zhang, K., Zhang, X., and Liu, L., 2018, The morphology-property effect and synergetic catalytic effect of CdS as electrocatalysts for dye-sensitized solar cells, ECS J. Solid State Sci. Technol., 7 (6), P311-P316.

[35] Yeh, C.Y., Lu, Z.W., Froyen, S., and Zunger, A., 1992, Zinc-blende-wurtzite polytypism in semiconductors, Phys. Rev. B, 46 (16), 10086-10097.

[36] Ganesh, R.S., Sharma, S.K., Durgadevi, E., Navaneethan, M., Binitha, H.S., Ponnusamy, S., Muthamizhchelvan, C., Hayakawa, Y., and Kim, D.Y., 2017, Surfactant free synthesis of CdS nanospheres, microstructural analysis, chemical bonding, optical properties and photocatalytic activities, Superlattices Microstruct., 104, 247-257.

[37] Phuruangrat, A., Thongtem, T., and Thongtem, S., 2009, Characterization of cadmium sulfide nanorods prepared by the solvothermal process, Mater. Lett., 63 (17), 1562-1565.
[38] Alkire, R.C., Kolb, D.M., Lipkowski, J., and Ross, P.N., 2010, Photoelectrochemical Materials, and Energy, Conversion Processes, Wiley-VCH, Hoboken, New Jersey, USA.

[39] Jiang, J.B., Huo, P., Wang, P., Wu, Y.Y., Bian, G.Q., Zhu, Q.Y., and Dai, J., 2014, Synthesis and photocurrent responsive properties of $\mathrm{CdS} / \mathrm{Se}$ clusters integrated with methylviologen, J. Mater. Chem. C, 2 (14), 2528-2533.

[40] Akpan, U.G., and Hameed, B.H., 2009, Parameters affecting the photocatalytic degradation of dyes using $\mathrm{TiO}_{2}$-based photocatalysts: A review, $J$. Hazard. Mater., 170 (2-3), 520-529.

[41] Houas, A., Lachheb, H., Ksibi, M., Elaloui, E., Guillard, C., and Herrmann, J.M., 2001, Photocatalytic degradation pathway of methylene blue in water, Appl. Catal., B, 31 (2), 145-157.

[42] Chen, Q., Bai, J., Li, J., Huang, K., Li, X., Zhou, B., and Cai, W., 2014, Aerated visible-light responsive photocatalytic fuel cell for wastewater treatment with producing sustainable electricity in neutral solution, Chem. Eng. J., 252, 89-94.

[43] Zhang, B., Fan, W., Yao, T., Liao, S., Li, A., Li, D., Liu, M., Shi, J., Liao, S., and Li, C., 2016, Design and fabrication of a dual-photoelectrode fuel cell towards cost-effective electricity production from biomass, ChemSusChem, 10 (1), 99-105. 